Огляди літератури, оригінальні дослідження, погляд на проблему

удК 616.379-008.64+616.6-036.12]-06:616.153.3-091.8

DOI 10.11603/1811-2471.2016.v0.i4.7072

\title{
ДИНАМІКА ПОКАЗНИКІВ АПОПТОЗУ ЛЕЙКОЦИТІВ КРОВІ У ПАЦІЕНТІВ, ХВОРИХ НА ЦУКРОВИЙ ДІАБЕТ 2 ТИПУ ТА ХРОНІЧНУ ХВОРОБУ НИРОК
}

\author{
๑Л.З. Вонс, Л. П. Мартинюк, В. К. Водвуд
}

ДВНЗ «Тернопільський державний медичний університет імені І. Я. Горбачевського МОз України»

\begin{abstract}
РЕЗЮМЕ. Метою нашого дослідження було визначити динаміку показників апоптозу лейкоцитів крові у хворих на цукровий діабет (ЦД) 2 типу та хронічну хворобу нирок (XXH) I-V стадії.

Під нашим спостереженням знаходилась група із 98 пацієнтів, із них з XXH I-V стадія та ЦД 2-го типу - 73 хворих та 25 досліджуваних контрольної групи.

КЛЮчОВІ СЛОВА: хронічна хвороба нирок, цукровий діабет, апоптоз лейкоцитів крові.
\end{abstract}

Вступ. У світі існує тенденція до невпинного зростання кількості хворих на хронічну хворобу нирок. Серед хворих на XXН пацієнти з ураженнями нирок, що розвинулись на тлі цукрового діабету, посідають 3 місце $[2,7,10]$.

За даними ВООЗ, ЦД входить до п'ятірки найнебезпечніших хронічних неінфекційних захворювань $[2,3,10]$. За прогнозами ВООЗ, до 2025 року число хворих на ЦД у розвинених країнах збільшиться на $51 \%$, а у тих, що розвиваються - на $170 \%$; діабетична хвороба нирок (ДХН) при ЦД 2-го типу складе 12-26 \% [13], до 2030 року понад півмільярда мешканців Землі матимуть цю патологію [3].

Щорічний приріст поширеності ЦД в Україні складає близько 4,4 \% (Дядык А.И. и соавт., 2010), ця тенденція відповідає світовій. Станом на кінець 2015 року, згідно з даними «Інституту ендокринології та обміну речовин ім. В. П. Комісаренка НАМН України», нараховується 1 млн 198,5 тис. хворих на ЦД (без врахування жителів Автономної республіки Крим, окупованих частин Луганської та Донецької областей). При цьому слід зазначити, що число хворих збільшується за рахунок хворих на ЦД 2 типу $[2,10]$.

Одним з найзагрозливіших ускладнень ЦД $\epsilon$ ураження нирок. У 20-30 \% хворих реєструють ДХН, серед хворих, які отримують замісну ниркову терапію, особи з ДХН становлять близько 40-50 \% $[2,10]$. Від ХНН вмирає 10-20 \% людей з ЦД $[2,3]$.

ДХН - специфічне мікросудинне ураження клубочків і тубуло-інтерстиціальної тканини нирок при ЦД, яке призводить до формування вузликового або дифузного гломерулосклерозу, внаслідок чого розвивається хронічне захворювання нирок $[4,6,7]$.

Важливим завданням $€$ пошук нових методів визначення темпів розвитку діабетичної хвороби нирок (ДХН) та прогресування ХХH, з метою запобігання чи відстрочення настання термінальної стадії ниркової недостатності $[3,4,13]$, оцінки адекватного лікування. Одним із таких маркерів може бути визначення апоптозу лейкоцитів крові.
Клітинний гомеостаз у здоровому організмі підтримується завдяки балансу між загибеллю клітин і їх проліферацією. Порушення контролю клітинної загибелі, наслідком якої $\epsilon$ посилення апоптозу та порушення гомеостазу, призводить до розвитку багатьох патологічних процесів в організмі, розвитку цілого ряду захворювань, зокрема і ЦД [5, $6,9,11]$. У ряді досліджень доведено, що тривалість більшості захворювань залежить від рівня апоптичної активності лейкоцитів крові $[6,11]$.

До важливих регуляторів апоптозу належать індуктори загибелі клітин: поверхневий рецептор Fas (CD95, APO-1), білки сімейства Bcl-2, які інгібують апоптоз $[5,8]$. Останнім часом активно досліджується біологічна активність білків, які належать до сімейства анексинів, зокрема анексин А5 (вони не виділяються з нормальних клітин, їх поява зумовлена руйнуванням клітин, апоптозом) [8]. Пропідіум йодид (Pi) $\epsilon$ маркером клітин, які перебувають в термінальній стадії апоптозу чи некрозу клітин, при якому порушується цілісність клітинної мембрани, і це дозволяє Рі війти в клітину і зв'язатися з ДНК [8].

Мета дослідження - проаналізувати показники апоптозу лейкоцитів крові у хворих на цукровий діабет 2 типу та хронічну хворобу нирок I-V стадії.

Матеріал і методи дослідження. В дослідження було включено 98 пацієнтів, з них хворих на XXН I-V стадії та ЦД 2-го типу було 73, 25 досліджуваних склали контрольну групу.

Серед обстежених пацієнтів було 33 чоловіки - 45 \% і 40 жінок - 55 \%, вік обстежених був від 44 до 76 років, середній вік склав $(58,8 \pm 1,3)$ років. Тривалість ЦД 2 типу в анамнезі у хворих становила від кількох місяців до 27 років, середня тривалість - $(11,57 \pm 0,70)$ років; тривалість ХХH - від кількох місяців до 24 років, середня тривалість $(2,77 \pm 0,35)$ років.

Стадію XXН визначали за ШКФ, визначеною за формулою CKD-EPI. Діагноз встановлювали згідно з прийнятою II Національним з'їздом нефрологів в 2005 році класифікації хвороб сечової системи. 
Огляди літератури, оригінальні дослідження, погляд на проблему

Для оцінки апоптозу лейкоцитів крові використовували ФІТЦ-мічений анексин $\vee$ з набору реагентів «ANNEXIN V FITC» («Beckman Coulter», США. Аналіз проб проводили на проточному цитометрі Epics XL («Beckman Coulter», CША) з аргоновим лазером, визначаючи декілька параметрів: мале кутове світлорозсіювання (FSC), що характеризує розмір клітини, бічне світлорозсіювання (SSC), що характеризує цитоплазматичні, а також мембранні особливості клітини, і показник зеленої флуоресценції (флуоресцеїн ізотіоціанат - ФІТЦ - 530 нм). Досліджувану популяцію клітин гейтували в координатах FSC (вісь абсцис) і SSC (вісь ординат), потім аналізували на наявність флуоресценції в координатах на основі Dot Plot. Використовували автоматичне програмне забезпечення і методи збору та аналізу даних $з$ високою роздільною здатністю (1024 канали). Отримані результати представляли у відсотках (співвідношення числа анексин-позитивних клітин (Ап) до загальної кількості фракції лейкоцитів). Нормою вважали вміст Ап в межах $(18,0 \pm 1,0) \%$, вміст Рі в межах $(0,9 \pm 0,4) \%$.
Отримані дані досліджень були піддані статистичній обробці, для цього використовували пакет прикладних програм Statistica (StartSoft USA, v.12). Застосовували методи непараметричної статистики: дисперсійний аналіз з використанням F-критерію Фішера, для перевірки нульової гіпотези; рангові кореляції Спірмена, для встановлення наявності та сили зв'язку між досліджуваними показниками. Статистично значущими вважали відмінності при $р<0,05$.

Результати й обговорення. Всі пацієнти, залежно від швидкості клубочкової фільтрації (ШКФ), були поділені на 5 груп. В 1 групу ( $n=15)$ увійшли пацієнти з XXН I ст. (ШКФ $\left.\geq 90 \mathrm{Mл} / \mathrm{XB} / 1,73 \mathrm{M}^{2}\right)$; в 2 групу ( $\mathrm{n}=22)$ хворі з ХХH II ст. (ШКФ - 89-60 мл/ Хв/1,73 $\left.\mathrm{M}^{2}\right)$; в 3 групу ( $\left.\mathrm{n}=15\right)$ хворі з XXH III ст. (ШКФ - 59-30 мл/хв/1,73 $\left.\mathrm{M}^{2}\right)$; в 4 групу $(n=10)$ хворі з XXH

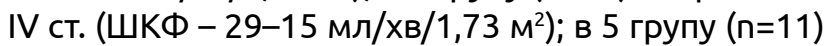

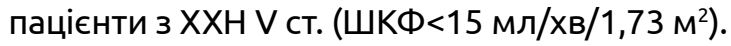

В нашому дослідженні було простежено залежність показників апоптозу лейкоцитів крові (An, Рі) від стадії XXН (рис. 1, 2).

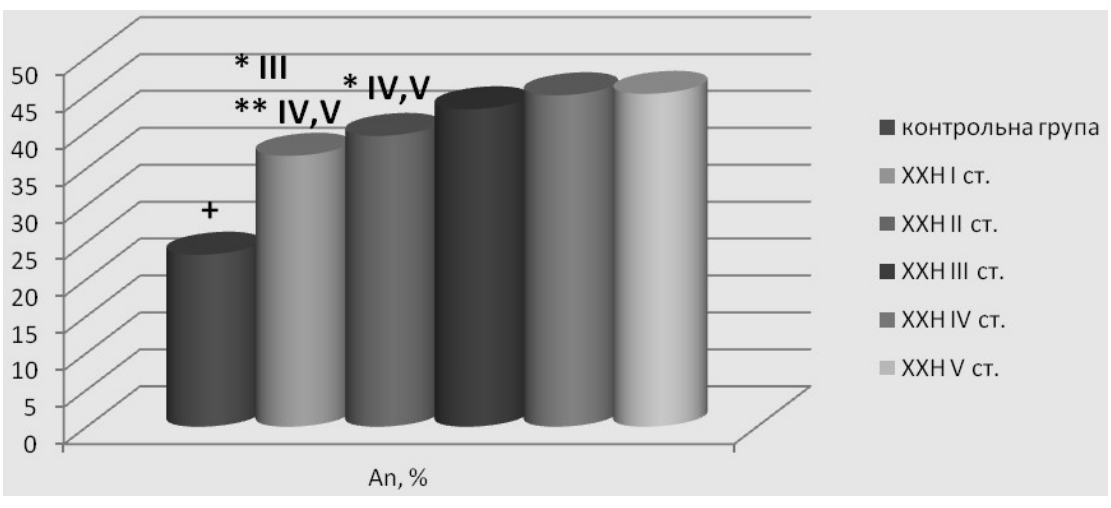

Примітки:

1. ** - достовірність різниці показників між різними групами $(p<0,01)$;

2. * - достовірність різниці показників між різними групами $(p<0,05)$;

3. +- достовірність $(p<0,01)$ між контрольною групою та пацієнтами з XXH I-V ст.

Рис. 1. Залежність показників апоптозу лейкоцитів крові Ап від стадії XXH.

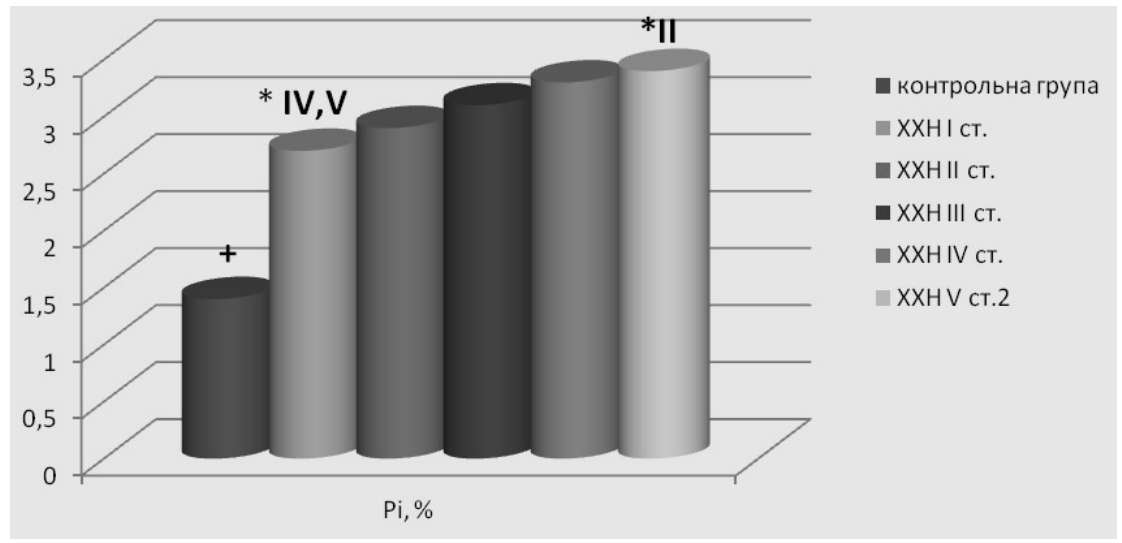

Примітки:

1. *- достовірність різниці показників між різними групами $(p<0,05)$.

2. +- достовірність $(p<0,01)$ між контрольною групою та пацієнтами з XXH I-V ст.

Рис. 2. Залежність показників апоптозу лейкоцитів крові Рі від стадії XXH. 
Огляди літератури, оригінальні дослідження, погляд на проблему

Як видно із діаграм, з прогресуванням XXH зростає кількість апоптичних клітин. Виявлено достовірну різницю між показниками An, \% у пацієнтів контрольної групи (23,3 $\pm 0,6 \%) ; \mathrm{Pi}, \%(1,4 \pm 0,1 \%)$ та обстежуваними на XXH I-V ст. $(p<0,01)$. Провівши дисперсійний аналіз між хворими з різними стадіями XXН ми отримали наступні результати: An, \% (F-критерій Фішера 4,68; p=0,0021) та $\mathrm{Pi}, \%$ (F-критерій Фішера 2,41; $\mathrm{p}=0,05)$. Окрім цього, отримана достовірна різниця показників An, \% $(p<0,05)$ у пацієнтів на XXH I ст. $(36,7 \pm 2,0 \%)$ та XXH III ст. $(43,0 \pm 1,6 \%) ; X X H$ II ст. $(39,4 \pm 1,1 \%)$ та XXH IV ст. $(44,9 \pm 1,8 \%)$ i XXH V ст. $(45,1 \pm 1,9 \%) ; \mathrm{Pi}, \%$ XXH I ст. $(2,7 \pm 0,2 \%)$ та XXH IV ст. $(3,3 \pm 0,2 \%)$ і XXH V ст.

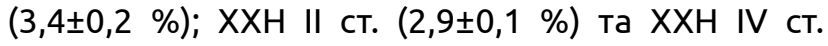
$(3,3 \pm 0,2 \%)$. Нами отримано достовірну різницю показників An, \% $(p<0,01)$ у пацієнтів з XXH I ст.
$(36,7 \pm 2,0 \%)$ та XXH IV ст. $(44,9 \pm 1,8 \%)$ і XXH V ст. $(45,1 \pm 1,9 \%)$.

Апоптоз лейкоцитів крові у хворих з XXH I-V стадії та ЦД 2 типу вивчений недостатньо, дані про це мало відображені в доступній нам літературі. Проведено ряд досліджень $[1,5,9,11,12]$, в яких вивчалися зміни, які відбуваються в організмі хворих на ЦД або при XXН, які виникли на фоні різних захворювань. Було доведено, що з прогресуванням хронічних захворювань зростає активність проапоптозного фактора та знижується рівень антиапоптозного $[1,5,12]$.

Нами встановлено прямі кореляційні зв'язки між Рі та набряками ( $r=0,232 ; p=0,049)$. Обернені кореляційні зв'язки між ШКФ та An ( $r=-0,462$; $p=0,000)$ - pис. 3 та $P i(r=-0,343 ; p=0,000)-p$ с. 4 , між Рі та білком плазми $(r=-0,283 ; p=0,015)$.

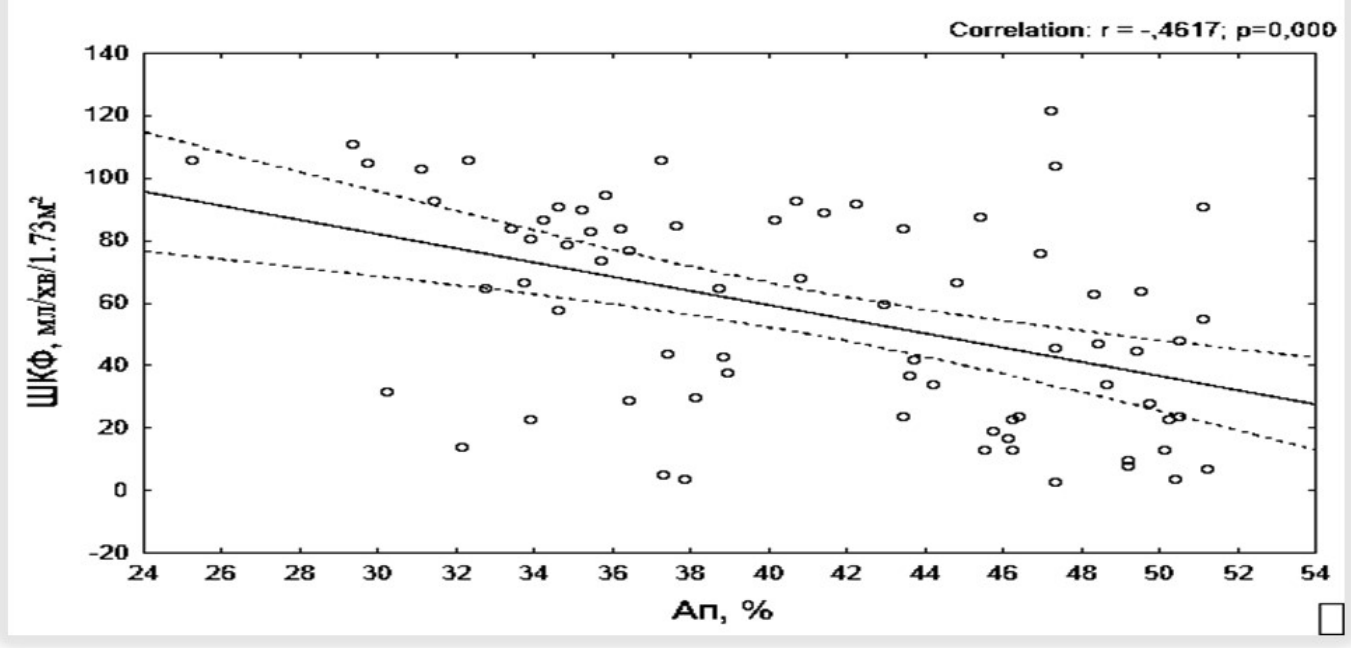

Рис. 3. Кореляція між ШКФ та рівнем Ап у крові хворих.

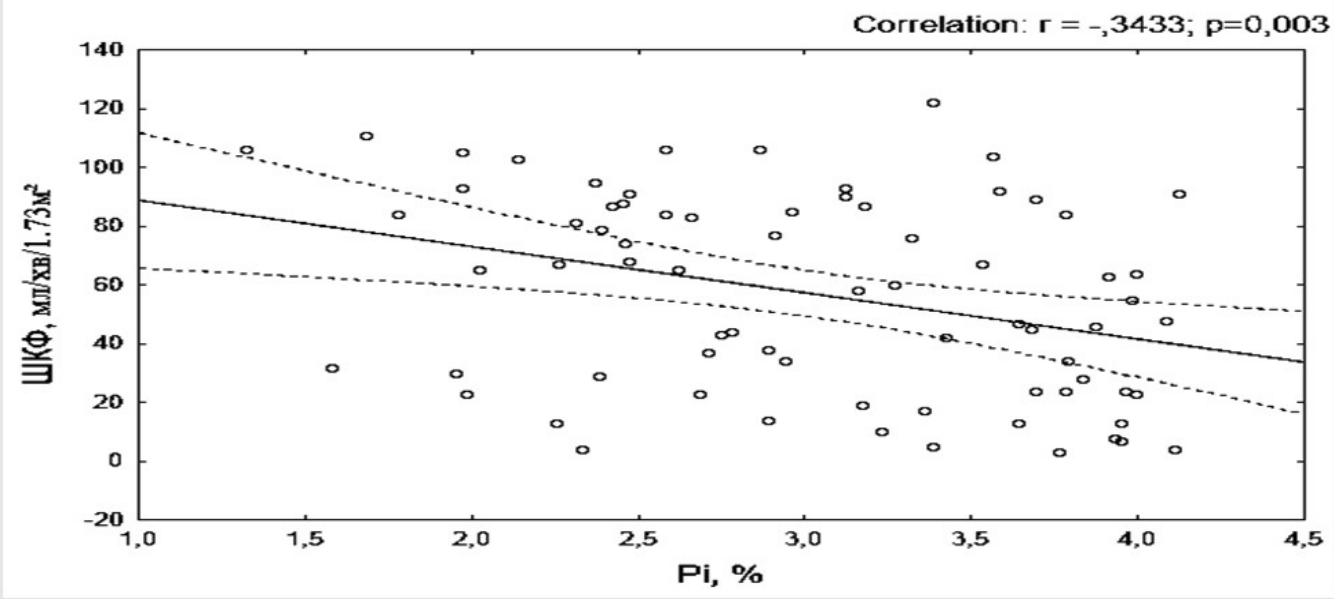

Рис. 4. Кореляція між ШКФ та рівнем Рі у крові хворих. 
Огляди літератури, оригінальні дослідження, погляд на проблему

Отже, з прогресуванням ХХН у хворих на ЦД 2-го типу погіршуються показники апоптозу лейкоцитів крові.

Висновки. 1. Встановлено обернені кореляційні зв'язки між швидкістю клубочкової фільтрації та анексином $(r=-0,462 ; p=0,000)$ та пропіоній йодидом $(r=-0,343 ; p=0,000)$.

2. Нами встановлено зростання показників апоптозу лейкоцитів крові з прогресуванням хронічної хвороби нирок у хворих на цукровий діабет 2-го типу: анексин (An) при I ст. $(36,7 \pm 2,0)$ та при

\section{ЛІТЕРАТУРА}

1. Бурлака $\epsilon$. А. Порушення в системі контролю апоптозу при хронічному гломерулонефриті в дітей / $\epsilon$. А. Бурлака // Клінічна та експериментальна патологія. - 2013. - Т. 12, № 4. - С. 44-48.

2. Дедов И. И. Сахарный диабет - проблема XXI / И. И. Дедов // Врач. - 2000. - № 1. - С. 4-5.

3. Каминский А. В. Сахарный диабет: новые взгляды и старые заблуждения. Часть 2. Профилактика сахарного диабета 2-го типа / А. В. Каминский // Міжнародний ендокринологічний журнал. - 2012. - № 4. - С. 42-45.

4. Лобода О. М. Механізми розвитку та прогресування діабетичної нефропатії / О. М. Лобода, І. О. Дудар, В. В. Алєксєєва // Клінічна імунологія. Алергологія. Інфектологія. - 2010. - № 9-10. - С. 46-50.

5. Мерецький В. М. Взаємозв'язок між оксидативним стресом і інтенсивністю апоптозу нейтрофілів при черепно-мозковій травмі і цукровому діабеті // В. М. Мерецький, М. М. Корда // Світ медицини та біології. - 2013. - № 4. - С. 75-78.

6. Механізми нефропротекторного впливу актовегіну у хворих на діабетичну нефропатію / І. І. Топчій, Ю. С. Якименко, П. С. Семенових [та ін.] // Український журнал нефрології та діалізу. - 2015. - № 4 (48). - С. 26-30.

7. Національний реєстр хворих на хронічну хворобу нирок : 2010 рік / уклад. Н. І. Козлюк, Г. С. Владзієвська, М.В.Кулизький ; Академія медичних наук України, Міністерство охорони здоров'я України,
$\mathrm{V}$ ст. $(45,1 \pm 1,9) \mathrm{XXH}(\mathrm{p}<0,01)$, пропіоній йодид (Pi) при I ст. $(2,7 \pm 0,2 \%)$ і при V ст. $(3,4 \pm 0,2 \%)(p<0,01)$.

3. Проведені дослідження обґрунтовують доцільність визначення цих показників у хворих на цукровий діабет 2 типу та хронічну хворобу нирок з метою прогнозування перебігу захворювання та оцінки адекватності лікування.

Перспективи подальших досліджень. Вивчення показників апоптозу лейкоцітів анексин $(\mathrm{An})$, пропіоній йодид (Pi) у пацієнтів, хворих на цукровий діабет II типу та хронічну хворобу нирок після проведеного лікування.

Державна установа «Інститут нефрології АМН України»; гол. ред. М. О. Колесник. - К., 2011. - 89 с.

8. Петрищев Н. Н. Содержание растворимых маркеров апоптоза и циркулирующих аннексин v-связанных апоптотических клеток в крови больных острым коронарным синдромом / Н. Н. Петрищев, Л. В. Васина, А. В. Луговая // Весник Санкт-Петербургского Университета. Сер. 11. Медицина. - 2008. - Вып. 1. - С. 14-23.

9. Роль гіпоксія-індукованого апоптозу в прогресуванні хронічного гломерулонефриту у дітей / В. Г. Майданик, Є. А. Бурлака, І. В. Багдасарова [та ін.] // Український журнал нефрології та діалізу. - 2014. - № 4 (44). - С. 41-45.

10. Стан ендокринологічної служби України та перспективи розвитку медичної допомоги хворим з ендокринною патологією / Ю. О. Гайдаєв, М. П. Жданова, Н. М. Боднарук [та ін.] // Міжнародний ендокринологічний журнал. - 2006. - № 2 (4). - С. 9-14.

11. Цаликова Ф. Д. Апоптоз в патогенезе нефропатий / Ф. Д. Цаликова // Нефрология и диализ. - 1999. - № 5. - С. 1-6.

12. Vanags D. M. Protease involvement in fodrin cleavage and phosphatidylserine exposure in apo ptosis / D. M. Vanags, S. Coppola, D. H. Burgess // Biol. Chem. 1996. - Vol. 271, № 49. - P. 31075-31085.

13. Yarmola T. I. [Specifics of diabetic nephropathy in patients with secondary hypertension general practitioners - family medicine] / T. I. Yarmola // Ukrainian Journal of Nephrology and Dialysis. - 2015. - № 3 (47). - P. 34-39.

\title{
DYNAMICS OF APOPTOSIS INDICATORS OF WHITE BLOOD CELLS OF PATIENTS HAVING DIABETES TYPE 2 AND CHRONIC KIDNEY DISEASE
}

\author{
○L. Z. Vons, L. P. Martyniuk, V. K. Vodvud \\ I. Horbachevsky Ternopil State Medical University
}

SUMMARY. The aim of our study was to determine the change in white blood cell apoptosis rates in patients on diabetes mellitus (DM) type 2 and chronic kidney disease (CKD), the I-V stage.

We observed a group of 98 patients, of which the I-V CKD stage and diabetes type $2-73$ patients, 25 people - the control group.

KEY WORDS: chronic kidney disease, diabetes, apoptosis of leukocytes. 